A TTEOR'S ARSTRACT OF THIS PAPER ISSUED BY THE BIBLIOGRAPHIC SERYICE, DECEMBER I5

\title{
VESTIGIAL GILL-FILAMENTS IN CHICK EMBRYOS WITH A NOTE ON SIMILAR STRUCTURES IN REPTILES
}

\author{
EDWARD A. BOYDEN \\ Harvard Medical School, Boston, Massachusetts \\ THREE TEXT FIGURES AND FOUR P'LATES
}

Since Rathke's discoveries in 1825 , biologists have been interested in the branchial region of amniotes as supplying the most conspicuous example of the persistence of ancestral structures in the higher vertebrates. But no record has yet appeared, with the possible exception of Grosser's note on young human embryos, which reveals the presence of any structures on the gill arches of reptiles, birds or mammals, that can be interpreted as functional or rudimentary gill filaments. Rathke, indeed, described small, obliquely-placed plates (Blättchen) on the gill arches of mammalian embryos but in 1832 he stated that their irregular appearance made him very suspicious, and when he examined them more carefully, in a sheep embryo which had been in spirits some weeks, he became convinced that the leaflets were merely broken-down fragments of delicate branchial epithelium.

While studying the anatomy of the five-day chick and unaware of Rathke's earlier attempt to find gills in mammals, my attention was attracted to ectodermal proliferations, protruding from behind the hyoid arch, which seemed to be involved in the obliteration of the cervical sinus. ${ }^{1}$ To Professor F. T. Lewis I am indebted for the suggestion that these projecting cell clusters might

1 These were described briefly on page 18 of the following paper: "An anatomical study of the $13 \mathrm{~mm}$. chick; a contribution to the comparative embryology of birds and mammals." (Manuseript deposited in Harvard College Library, June 1916.) See also Proe. Am. Assoe. Anat., Anat. Rec., vol. 10, 1916, p. 185; vol. 11, 1917 , p. 329 . 
be brought into line with the gill filaments of amphibians and fishes. Subsequent study of older and younger chick embryos, together with the finding of similar structures in reptilian embryos, seems to warrant such a conclusion and the presentation of this material from a phylogenetic standpoint.

\section{ORIGIN AND EARLY DIFFERLNTIATION OF GILL-FILAMENTS IN THE CHICK}

The history of these filaments, covering a period from the beginning of the fourth to the middle of the eighth day, occupies nearly one-fifth of the total period of incubation. Throughout this time the epithelium of the filaments themselves as well as the branchial epithelium which gives rise to them is characterized by the presence of what appear to be degeneration resicles. These accompany, and thus may be said to register, an activity of the epithelium of which the filaments seem to be the fruition. They first appear in the entoderm, but later arise in the adjacent ectoderm, where they come to exist in greatest numbers. As early as the seventy-six hour stage 'Harvard Embryological Collection, Series 2057, $6.8 \mathrm{~mm} ., 76$ hours; and Ser. 1953, $8.0 \mathrm{~mm} ., 78$ hours) the first of them may be seen in the posterior or posteromedial walls of the first four pharyngeal pouches at a time when the first three gill clefts have broken through and the fourth pouch touches the ectoderm (figs. 4 and 10). When complete, each vesicle is a clear sphcrical cyst, embedded in the epithelium, measuring some twelve to twenty microns in diameter, that is from two to three times the size of the erythroblasts in neighboring blood vessels. Each is surrounded by a wall of its own, comparable in thickness to a nuclear membrane, the whole enclosing pyenotic nuclei and cytoplasmic fragments in different stages of degeneration. Favorable sections, such as figure 25, indicate that these cysts result from the nearly simultaneous disintegration of adjacent epithelial cells. In places where two or more cysts have coalesced, the resulting structure often bears a superficial resemblance to capillaries containing corpuscles in the underlying mesenchyma, but the most careful search fails to reveal any direc relation between the two. Of interest, in con- 
nection with the fact that the vesicles first appear in the entodermal walls of the gill clefts, is the observation, based on the work of Greil and others, that it is the entoderm of the pouches of frogs and toads, which initiates the process of gill formation. This it does by spreading out from the distal ends of the pharyngeal pouches on either side of a cleft until the ectoderm that covers the arches has become partly, and in some species completely, underlaid by a new layer of entoderm which has interpolated itself between the ectoderm covering the arches and the mesenchyma upon which the ectoderm formerly rested.

Following the first appearance of cysts in the chick, scattered vesicles may arise in the walls of all the pharyngeal pouches and in the ectoderm between the clefts on the outside. Toward the end of the fourth day they become most numerous in the ectoderm between the second and third clefts, where the degeneration is so rapid that pycnotic nuclei may appear anywhere in the epithelium without grouping themselves into vesicles and in sufficient numbers to give the epithelium a punctate appearance. Eventually most of them are crowded down into the underlying tissues. A second, less conspicuous concentration area occurs in the ectoderm between the third and fourth clefts. In frogs and toads it is the ectoderm of these two arches which evaginates to form the first external gills.

Before describing the further development of the epithelium, it is desirable to review the changes in the branchial arches as seen from the outside. Figure 4 represents these arches at the stage when the epithelial vesicles first appear. It will be noted that the hyoid arch is already larger than the others, that the third arch has become somewhat wedge-shaped and smaller, and that on account of this differentiation the branchial region as a whole has lost that regularity of arches and clefts so characteristic of early stages in all vertebrate embryos. In the next figure these differences are still further accentuated, the three-cornered hyoid arch dominating the whole region, while the posterior arches are depressed into a sinus below the general level of the neck and are correspondingly reduced. In certain fishes and amphibians it is the posterior margin of this second arch, now known as an 
operculum or gill cover, which grows back over the sinus behind it, enclosing the third and fourth arches with their filaments in a branchial chamber. In the later stages of the chick this arch undertakes a similar backward extension, the significance of which was first appreciated by Rathke, the pioneer discoverer of gill clefts in amniote embryos. ${ }^{2}$ In the wingless bird Apteryx (Parker), and in Struthio (Nassonow), the opercular fold to which this backward extension gives rise is said to be a very conspicuous object, much more so than in the other amniotes, although in all vertebrates, the hyoid is larger than any of the other arches. ${ }^{3}$ Thus the persistence of this peculiar development of the hyoid arch through the whole vertebrate series is almost as striking as the persistence of the arches and diverticula themselves. In the light of this fact the presence of filamentous structures behind the operculum takes on added significance.

Returning to the discussion of figure 5, a careful examination of the third arch reveals a small hillock or mound just behind the point of the hyoid,- - between the point and the third ectodermal groove. In fresh specimens observed under salt solution, this mound is distinctly whiter than the surrounding tissue and is the first external indication of the appearance of filaments. Serial sections of a slightly older stage than that referred to in

\footnotetext{
2 "Am vierten und fünften Tage der Bebrütung kommen auf jeder Seite in der Substanz des Halses drei aufeinander folgende fast linsenformige Höhlen zum Vorschein, deren jede nach aussen und innen geöffnet ist. Die äussere Mündung der vorderston Höhle wird übrigens von einem Theile, der ̈̈hnlich dem Kiemendeckel der Fisehe ist, verdeckt." ('25)

In a much later publication ('61) the same author earries the analogy still farther. "Von dem zweiten Schlundbogen, in welchem sich ein Zungenbeinhorn ausbilden soll, wächst bald darauf, nachdem sich die vordeste Schlundspalte geschlossen hat, ein klappenartiger Fortsatz hervor, der die zweite Schlundspalte bedeckt und als eine Andeutung der Membrana branchiostega der Grätenfische betrachtet werden darf."

"Parker on Apteryx: "The backward extension of the hyoidean fold visible in the previous stages has increased so as to form a true operculum, which completely covers the third cleft, so that it is invisible in an external view. The fourth cleft. . . . lies immediately behind the operculum, and is very probably only exposed by the shrinking of the latter. . . . . The retention of so obviously anphibian a charaeter . . . . appears to be a character of very considerable morphological interest."
} 
plate 2 (see figs. 12 to 17 inclusive) show that the mound is an evagination of the thickened, vesiculated ectoderm covering the third arch, and contains a mesodermal core, thus almost reproducing the early formation of external gills in the amphibia. The lower end of it has already begun to develop filaments and later the upper end will give rise to tufts of cells (fig. 18). In the same embryo the ectoderm of the fourth arch forms an evagination, which-however, is solid, and in this specimen much smaller, tending to fuse with that from the third arch (fig. 15). Owing to the rapidity with which the region behind the third arch is being flattened out, the evagination on the fourth arch, which has been observed in several embryos, has only a transitory existence of its own. As the operculum extends backward all of the third arch except the mound becomes covered over, while the mound itself gradually assumes the shape of a wedge, with filaments at its downward directed point, as indicated in figures 6 and 19. As the hyoid arch continues its backward growth during the fifth day it fuses with the third arch in such a way as to carry with it on its under surface the tufted epithelium at the lower end of the wedge, so that from now on, the filaments of this region of fusion will appear to come from the under surface of the operculum (figs. 19 and 23). By the beginning of the sixth day the whole edge on each side has become differentiated into a ridge coextensive with the lateral margins of each operculum (fig. 7). Serial sections (fig. 24) show that the individual filaments borne by the ridge are solid outgrowths of the epithelium, honeycombed with degeneration vesicles. With the appearance of this pair of ridges the first half of the life-history of the filaments may be said to have been completed.

While this differentiation of filaments has been going on at the margins of the hyoid arches, the ventro-medially directed portions of the two opercular processes have united to form a single band of tissue slightly overlapping the pectoral body-wall and extending across the ventral surface of the neck from side to side, - the homologue of the membrana branchiostega according to Rathke. From now on, the fused hyoid arches may therefore be referred to as a single structure, the plica opercularis, pos- 
sessing two lateral margins, each fused to the side of the neck and bordered by a line of filaments, and a single pectoral margin whose free edge is directed posteriorly. A notch at its middle point (incisura opercularis) indicates the place where the two arches originally united, and a tubercle on each side of the notch still further accentuates the paired origin (fig. 1). In later stages the free, overhanging, pectoral margin becomes more and more encroached upon by the lateral margins, as its under surface progressively fuses with the surface of the neck, from the sides to the mid-line. As these lateral zones of fusion pass slowly inward they carry the lines of filaments with them so that these likewise come to lie successively nearer the mid-line. Meanwhile the pectoral wall below the opercular fold has developed a pair of surface markings of its own which begin to shift their position from the sides to the mid-line at the same time and rate as the lines of filaments and zones of fusion above. Eventually these markings come to form part of a median ridge extending from the region below the operculum to the umbilicus. In addition to their migration these pectoral markings or ridges exhibit a further, albeit superficial, resemblance to the filaments in that the cell-proliferations of which they are made often contain scattered degeneration vesicles and pycnotic nuclei, but to a much lesser extent than obtains in the branchial epithelium. Because the pectoral ridges and lines of filaments are thus found to possess these common features it becomes necessary to establish the identity or the disparity of the two sets of structures, the one on the neck and the other on the pectoral wall,- -hence the following digression.

CHANGES IN THE PECTORAL WALL CORRELATED WITI THE LATER DEVELOPMENT OF FILAMTNTS AND OPERCUTIUM

During the latter part of the sixth day and the beginning of the seventh, four different sets of structures make their appearance in the pectoral wall, all of which are represented in figure 1: a pair of pectoral grooves (sulci peciorales);2) a pair of pectoral ridges (cristae pectorales); 3) a parr of mesothelial ridges (cristae mesotheliales) and 4) a median epitrichial ridge (crisla epitrichialis). 
The pectoral grooves first appear about the middle of the sixth day and at once delimit a roughly triangular area whose base coincides with the intersection of the neck and breast, and whose downward directed apex lies just above the umbilicus. At first the area cnclosed by these grooves is transparent throughout, revealing the outlines of the heart beneath. But almost immediately the basal third becomes vaseular and much thicker than

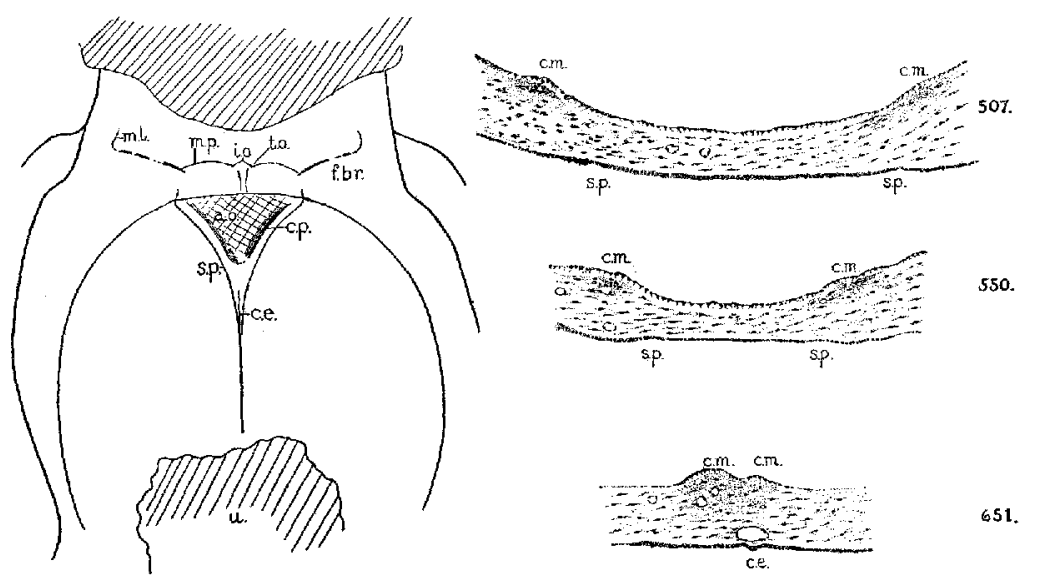

Fig. 1 Sketch of the markings on the pectoral wall of a seven-day chick ( $\mathrm{H}$. E. C., Ser. $2076 ; 17.3 \mathrm{~mm}$; 6 days, 7 hours) together with three transverse sections of the pectoral wall of the same embryo, $\times 42 \mathrm{diam}$. 507, section at level of c.p.; 550, section at level of s.p.; 651, section at level of c.e., m.l., and m.p., lateral and pectoral margins of opercular fold; i.o., opereular notch; t.o., operoular tubercle; f.br., row of branchial filaments; a.o., opaque area; c.p., pectoral ridge; s.p., pectoral groove; c.e., epitrichial ridge; c.m., mosothelial ridge; $\boldsymbol{u}$. umbilicus. Compare with frontal section of pectoral wall in figure 20 .

the apical portion which retains for some time its non-vascular and transparent character. In fresh specimens the upper portion exhibits a semi-opacity somewhat similar to that of ground glass. It is this part which at the beginning of the seventh day gives rise to a series of superficial evaginations which may appear anywhere in this area, but are chiefly ranged along the medial borders of the pectoral grooves. Ultimately those of a side become numerous enough to form a pair of pectoral ridges which in their later development, as previously noted, exhibit a super- 
ficial resemblance to the filaments when seen in section. About the same time a pair of sub-surface lines may be seen through the translucent wall underlying each groove. A study of serial sections (H. E. C., Ser. $2076 ; 6$ days, 7 hours; $17.3 \mathrm{~mm}$.; fig. 1) proves them to be mesothelial ridges projecting into the pericardial cavity.

Hardly have these lateral grooves and ridges appeared than they begin to shift their position from the sides of the embryo to the mid-ventral line. This takes place in such a way that the legs of the triangle first approach each other in front of the umbilicus and thereafter successively forward of that point, thus resulting in an apparent ascent of the apex of the triangle. This progressive movement is recorded on the median line by an eruption of epitrichial cells which follows the retreating apex up the pectoral wall until it reaches the surface ridges described above. Thus a Y-shaped ridge is produced on the ventral surface of the embryo the upper arms of which, the two surface ridges, form a broad angle, and the lower arm of which, the epitrichial ridge, extends to the umbilicus. Micrometer measurements of selected embryosindicate the rate at which the two upper arms are coming together. In an embryo of five days, twenty hours $(17.5 \mathrm{~mm}$.) the distance between the upper ends of the ridges is $1.64 \mathrm{~mm}$.; while in an older stage (6 days, 3 hours; 17.3 $\mathrm{mm}$.) it has been reduced to $0.91 \mathrm{~mm}$.; and in a still older embryo (6 days, 18 hours; $19.5 \mathrm{~mm}$.) to $0.31 \mathrm{~mm}$. The shifting of these superficial ridges also keeps pace with the shifting of the operculum and filaments to be described later, so that if the ridges wero continued upward at any given stage they would strike the tufts of filaments above. In all cases, however, the two structures are separated by an appreciable area of the neck. Eventually the surface ridges become heaped up in the median line thus constituting, with the, epitrichial proliferations, a continuous median ridge from the umbilicus to the neck. In its upper end the evidence of its paired origin is visible for some time and as a whole the ridge persists for a number of days even to the time when it becomes elevated upon the developing feather papillae (H. E. C., Ser. $1967 ; 11$ days, 0 hours; $31.0 \mathrm{~mm}$.). A similarly placed 
median ridge has been observed in a human embryo of $45.0 \mathrm{~mm}$. (H. E. C., Ser. 2079) and in a dog embryo of $14.0 \mathrm{~mm}$. (H. E. C., Ser. 2052), but I have been unable to discover any clue to its origin in these animals. It is possible that in mammals, only the last stages of the process are visible.

An examination of the inner surface of the pectoral wall shows that an approximation of the two mesothelial ridges is also taking place (fig. 1). In sectioned embryos each ridge was found to contain one or two small veins although no blood vessels could be detected in the area between the two ridges in their lower extent. This suggested a study of injected embryos which has strikingly substantiated the shifting of tissues in the pectoral wall.

The displacement of veins in the pectoral wall. In a five-day chick that portion of the body wall which covers the heart is entirely free from blood-vessels. On the margins of this roughly triangular area lies a capillary network, continuous with that which fills the rest of the membrana reuniens (Rathke's term for the thin somatic wall which originally covers the abdominal and thoracic viscera). This appears to be growing into the wall over the heart much as capillary-nets elsewhere invade non-vascular regions. By the middle of the sixth day (injected embryo 5 days, 7 hours; $12.4 \mathrm{~mm}$.) this network of the membrana reuniens has resolved itself into a series of radial veins converging upon the umbilicus from the myotomes. Those immediately adjacent to the non-vascular triangle (that is, under the pectoral grooves) converge upon the umbilical vein of their respective sides at the point where it enters the septum transversum, on either side of the apex of the heart. From now on, the non-vascular area over the heart will become more and more circumscribed, not by the ingrowth of new vessels (except in the uppermost part which is congruous with the opaque area previously described, where a capillary net grows down from the cervical region) but by a shifting of marginal veins already formed. These swing in on two pivotal points, the points referred to above, where the umbilical vein of each side enters the septum transversum. These radial venules are not straight lines but present a convex 
surface to the non-vascular triangle, so that as they swing in they first meet in the median line under the point where the epitrichial ridge first appears, and thereafter progressively anterior to this point. In an embryo of $15.5 \mathrm{~mm}$. (fig. 2) they are just reaching the mid-line for the first time. In an embryo of $18.5 \mathrm{~mm}$. (injected specimen 6 days, 0 hours), they have moved
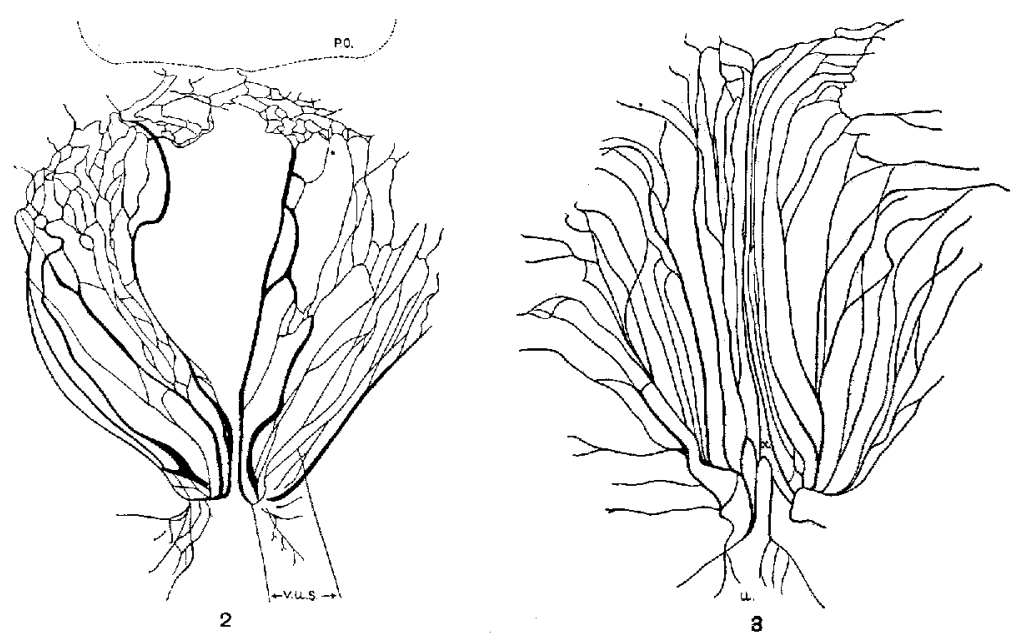

Fig. 2 Blood vessels in the pectoral body-wall of a $15.5 \mathrm{~mm}$. chick. Camera lucida drawing of injected embryo ji ( 6 days, 0 hours $) \times 15$ diam. Note the nonvascular area in the center and the capillary plexus above it which has grown down from the cervical region. p.o., opercular fold; v.u.s, left umbilical vein.

Fig. 3 Blood vessels in the pectoral wall of a $20.6 \mathrm{~mm}$. chick. Camera lucida drawing of injected embryo ka ( 7 days, 2 hours $) \times 15$ diam. Note the disappearance of the non-vascular area and the direction of the blood vesscls as compared with those in figure $2 . \quad u$., umbilicus; $x$., median line, on either side of which aro the right and left sets of marginal veins.

in upon the mid-ventral line as far up as the point where the epitrichial ridge meets the surface ridges, (the region of the truncus aorticus). Finally in an embryo of $20.6 \mathrm{~mm}$. (fig. 3), the area over the heart is completely filled with parallel longitudinal veins extending from the neck to the umbilicus. Thus in forty-eight hours the original marginal veins of each side have described an $\operatorname{arc}$ of $45^{\circ}$. 
As far as one can judge from the meagre description of the region in mammals, it seems probable that the pectoral wall is vascularized by a different method than that which obtains in the chick. Evan's figure of a fifteen millimeter pig embryo suggests that the pectoral wall is invaded by the same capillary net which grows down from the cervical region in the chick, but in this animal continues until it reaches the umbilicus. Kölliker's figure of a cow embryo of about the same stage suggests that this area is supplied by the capillary net which grows in from the marginal veins. Mall describes the condition in man as follows:

I have in my collection a well-preserved human embryo (no. LXXVI) (22 days), in which the membrana reuniens is filled with a plexus of veins much like that in the cow's embryo. . . . The ventral wall of the heart near the liver contains no vessels, while the membrana reuniens covering the upper end of the heart is filled with a plexus of vessels which communicate with the capillaries of the mandibular arch.

The study of the blood vessels thus confirms the testimony of the superficial markings, that there is a considerable shifting of body-wall tissues from the sides of the embryo toward the midventral line,- - this in advance of the later invasion of pectoral muscles, nerves, dermal and skeletal parts which enter into the formation of the definitive pectoral wall. Whether there is anything of this preliminary movement in other amniotes is difficult to determine from the evidence at hand. But certainly in chicks of the sixth and seventh days it is possible to demonstrate a medial displacement of tributaries of the umbilical veins and a shifting of an internal and external set of ridges. Although $I$ have been unable to find in the literature any record of such ridges or grooves as have just becn described, there is some evidence that the older embryologists who discussed this region in birds and reptiles saw something of this early shifting of tissues. Thus Rathke, the first to maintain that the muscle and skeletal elements of the breast wall did not arise in situ, believed that these structures grew in from the sides of the embryo in such a way as to push ahead of them the thin somatic wall which originally covered the thoracic and abdominal viscera, eventually causing the membrana reuniens to disappear completely (allmälig ver- 
schwinden). Remak, following Reichert, believed that the new elements did not displace the original wall but were merely incorporated into it as they grew in. ("Die sekundäre Bauchwand entsteht aus der Verschmelzung der unsprünglichen Bauchwand mit der hervorwachsenden Entwickelungsproducten der Urwirbel."). Although my own observations have resulted in the finding of new manifestations of a migration of tissues in the bodywall it is still very difficult to analyze the nature of the movements. It may be that at a certain stage in the development of the wall that part of the membrana reuniens which lies over the breast is being pushed in toward the median line by the faster growing lateral parts and reduced to a narrow zone,- - the slack, so to speak being taken up by the increasing thickness of the membrana and by the protrusion of certain external and internal ridges. Or it may be that this early shifting of structures is more in the nature of a preliminary growth-wave which is passing from vascular to non-vascular territory.

The difficulty of ana'yzing these changes, however, does not derogate from the conclusions which we may now form concerning the relation of the pectoral ridges and the branchial filaments, - to ascertain which this study of the pectoral region was first undertaken. As has been stated, both sets of structures are evaginations of surface epithelium, both move in toward the median line at certain stages in their development and both exhibit some degree of epithelial degeneration. But beyond these superficial resemblances there is nothing to indicate the existence of any genetic relation between them. At no period in their development are they in continuity nor do they even resemble each other in histological appearance, unless it be at the end of the seventh day, when the filaments have been crowded in upon the tubercles just prior to their disappearance. The differences which they exhibit may be summarized in the following paragraph.

The epithelial evaginations which constitute the ridges develop from a broad zone of thickened ectoderm situated on either side of the pectoral wall. The margins of each zone grade imperceptibly into the adjacent ectoderm so that its limits are never 
sharply defined. Apparently the limits vary considerably in different embryos. This variability may be said to characterize the whole development of the ridges, - a marked contrast to the regularity with which the filaments develop. As each zone shifts its position medially, scattered pycnotic nuclei appear between the epitrichial and basal layers of the epithelium and diffuse tufts of cells arise on its surface. The crests of these evaginations form a low ridge which becomes the more conspicuous the nearer the ridge approaches the mid-line. The filaments, on the other hand, grow out from a narrow strip of epithelium situated on the lateral margin of each operculum, a germinative zone which represents the fusion of the posterior wall of the hyoid arch with the ectoderm of the third and fourth gill arches. The filaments thus arise from a specific epithelium, - a portion of the branchial membrane, the whole of which is characterized at an early stage by the presence of degeneration vesicles. The filaments grow out of the region where the cysts occur in greatest numbers and are themselves honeycombed with vesicles. Furthermore, they do not differentiate into diffuse clusters of cells but into a row of more or less distinct evaginations. Again, the 'life cycle' of the filaments is staged from two to three days earlier than that of the ridges. The branchial evaginations first arise in situ and only later become involved in the movements of the ventral body wall, whereas the pectoral ridges are in process of migration when they first appear. Thus one is lead to consider whether the ridges are not more intimately connected with the movements of the body wall than are the filaments, if indeed they are not products of that movement. For as the ridges approximate each other they become heaped up in the midline to form a single structure which persists three days after the filaments have disappeared, whereas the latter never meet in the mid-line but maintain their identity as paired rows of individual filaments to the end. It may be that the pectoral ridges represent the survival of some similarly placed outgrowths in a lower vertebrate, but in no other animals, so far as I am aware, do any such structures exist. For the present, then, it seems more reasonable to define the ridges as local manifestations of migra- 
tion in the pectoral wall. But whatever interpretation they may receive it is evident that they belong in a different category from the filaments.

\section{LATFR DEVELOPMENT OF FIIAMENTS AND OPERCULUM}

The description of the early development of these structures has been carried to the point where the opercula of the two sides have united to form a swollen band of tissue across the ventral surface of the neck (the plica opercularis) the posterior edge of which (the margo pectoralis) slightly overlaps the pectoral wall. On the lateral margin of the fold (the margo lateralis), a line of filaments has been formed, which is separated from the one on the other side by the whole width of the neck. This is the condition at the middle of the sixth day when the opercular fold has reached its maximum length of two and a half to three millimeters. From now on, the neck will increase in diameter as the fold undergoes reduction. This process consists in the fusion of the under surface of the margo pectoralis with the ventral surface of the neck, so that its form is changed from an overhanging fold of tissue to a mound, which in turn flattens out and eventually disappears. The striking feature of the whole process is that it proceeds from the sides to the midline, at the exact rate and at the same time that the pectoral ridges and marginal veins are moving across the face of the pectoral wall. The rate of fusion is easily gauged by measuring the decreasing distances between the medial ends of the two rows of filaments as they are borne along on the advancing wave. In all cases they move synchronously with the structures below. Thus in an embryo of 5 days and 20 hours $(17.5 \mathrm{~mm}$.) the unfused or overhanging portion of the plica, measured by the distance between the filaments of the two sides, is $1.45 \mathrm{~mm}$. In the next seven hours it has been reduced in length to $0.55 \mathrm{~mm}$. (embryo of 6 days, 3 hours; 17.3 $\mathrm{mm}$.), and in the next fifteen hours to $0.23 \mathrm{~mm}$. (embryo of 6 days, 18 hours; $19.5 \mathrm{~mm}$.). The entire opercular fold including both overhanging and fused portions of the two sides measure as before some two and a half to three millimeters although the fused portion is in process of sinking into the neck and disap- 
pearing. By this time the projected width of the neck at this level measures some three and a half millimeters. In round numbers, during the twenty-four hours following the maximum development of the operculum the unfused portion has been reduced by eighty per cent of its former length while the neck has added twenty per cent to its circumference. By the beginning of the eighth day the united opercula have become reduced to a pair of tubercles on either side of the mid-ventral line which are themselves on the point of being incorporated in the neck.

While the opercular fold has been undergoing a decline, the filame ts have reached their maximum development and have likewise entered a period of decline which is completed with the disappearance of the tubercles. In the beginning it was stated that the filaments were solid outgrowths of cel's arising chiefly from the ectoderm covering the third branchial arch; that these filaments first appeared at the lower part of the evagination of that arch; then peripheral to this point as the mound assumed a wedge-shape and the wedge became compressed into a filamentbearing ridge, about half a millimeter in length. Such is the condition at the middle of the sixth day, at a time when the plica opercularis is coextensive with the width of the neck, and when the pectoral grooves and other evidences of the median migration first appear in the wall below (fig. 7).

As the zone of fusion between the under side of the opercular fold and the neck moves inward from its original position at the junction of the lateral and pectoral margins of each side, the row of filaments is carried with it. Concurrently each row increases its length until it reaches a maximum extent of nearly. a millimeter, and numbers some eight to a dozen separate filaments. These are often irregularly arranged and are sometimes grouped into two parallel rows. Starting with the medial end the small ones with which the line begins pass abruptly into large-size filaments which continue from a third to half way across the line. Lateral to this medial portion there are usually gaps in the line and the different members vary in height, tending however to become somewhat smaller as the lateral end is approached. At exactly what point new filaments are added to give the line 
its maximum extent or how the movement of the line as a whole across the neck is accomplished, is difficult to. determine. One is inclined to believe that the medial migration is an apparent rather than a real movement, brought about by the addition of new members to the medial end of the row, this end representing an advancing growth-zone superimposed upon the advancing zone of fusion between the operculum and the neck. In favor of this hypothesis is the fact that the medial half of the row exhibits the greatest solidarity, that the large medial filaments are the ones that are usually branched (fig. 20), and that the lateral members are the ones which drop out as the total length of the line diminishes. There is the other possibility, however, that the line as it stands is carried bodily inward, new filaments being added laterally (the order of formation in the earliest stages), or possibly interspersed among the old ones as the line is drawn out. Following the period of maximum development during the seventh day, the lateral members of the row gradually flatten out until, as the line approaches the center, only a few of the medial filaments on each side remain (fig. 9). By the beginning of the eighth day both the opercular tubercles and filaments have been absorbed into the neck.

During this shifting of the rows of filaments from the sides to the mid-line the under surface of the pectoral margin of the opercular fold between the right and left zones of fusion has given rise to a new line of filaments,--abortive structures which are so small that they cannot be made out with the naked eye. In fresh specimens, however, the margo pectoralis has that pearly lustre characteristic of the marginal filaments. These abortive filaments can just be made out with certainty in sections of seventh-day embryos (H. E. C., Ser. 1950; 6 days, 2 hours; 16.0 $\mathrm{mm}$.) (H. E. C., Ser. 2075; 6 days, 1 hour; $17.0 \mathrm{~mm}$.), where they appear as low sprouts of cells on the under surface of the opercular fold. The largest of these are to be found on the tubercles which lie on either side of the notch. As the marginal filaments move in, they push this secondary line ahead of them and at the end often form with these a confused tuft of cells just prior to the final disappearance of both filaments and operculum 
In figure 9 the primary and secondary series have maintained their identity to the end. In reviewing the origin of both series it will be seen that the posterior wall of the hyoid arch is potentially a filament-bearing surface as well as the walls of the third and fourth branchial arehes. This is in accord with what we know of conditions in gill-bearing vertebrates.

By way of a summary the history of these vestigial gill filaments in the chick may be divided into six stages: 1 , the appearance of degeneration vesicles in the branchial epithelium; 2 , the concentration of these in the ectoderm covering the third arch and, to a lesser extent that covering the fourth arch; 3 , the thickening of the ectoderm of these two vesiculated areas into tufted epithelial mounds, and, in the case of the third, an apparent evagination of the ectoderm with a mesodermal core; 4 , a gradual differenization of these areas (now crowded into one and fused with the sides of the backward growing operculum) into a transverse line of filaments on each side of the neck; 5 , a progressively medial displacement of this line, correlated with the medial migration of structures in the pectoral body-wall; 6 , a rather rapid reduction of this line and the eventual suppression of both filaments and operculum.

\section{GILL FILAMENTS IN REPTILES}

Although the branchial region of reptilian embryos exhibits some measure of transition between the higher amniotes and the gill-bearing vertebrates it is much more nearly akin to that of birds than to that of any other group. Particularly is this true with regard to the development of the hyoid arch, where in turtles, lizards, and alligators (as in birds) the opercular processes of the two sides unite to form a conspicuous fold of tissue aycross the ventral surface of the neck which persists long after all trace of the other gill arches has disappeared. Similarly, vestiges of filamentous structures behind the hyoid arch are to be found in at least three of the main groups of reptiles, although in a more transitory and less conspicuous form than obtains in the chick. That they are not developed to a higher degree in the former may be explained by the fact that living reptiles are themselves a 
modern and highly specialized group; and that the degree to which retrograding structures are developed does not necessarily correspond to the rank which the possessor of these structures holds in a graded phylogenetic series. The fact that these structures are present at all in reptilian embryos greatly increases the significance of the better developed filaments in the chick embryo.

In discussing the conditions in reptiles it should be borne in mind that considerably less material was available than in the study of the chicks where some seventy embryos between the sixth and ninth days of incubation were examined. Of the four reptile series in the Harvard Collection, which are sufficiently extensive to afford a fairly complete picture of the development of the branchial region, three of them, Lacerta, Eutaenia and Chrysemys, show epithelial outgrowths behind the hyoid arch which are identical with the filamentous structures found in the chick. The first of these, Lacerta muralis, presents a more primitive branchial system than is found in birds, five well-spaced ectoderma! grooves being visible from the outside at an early period. Later in its development the operculum fuses with the region behind the fourth arch in such a way as to form a peribranchial chamber into which portions of the third and fourth arches with their respective aortic trunks freely protrude (H. E. C., Ser. 813; $6.4 \mathrm{~mm}$.). Still later, when the branchial chamber has become obliterated, small epithelial proliferations appear from underneath the operculum in the region of its fusion with the posterior gill arches (H. E. C., Ser. 811. and $812 ; 7.4 \mathrm{~mm}$.). Although they have but a transitory existence they occur at the same relative time and place as the filaments in the chick, with the difference that the filaments in the birds appear on the third and fourth arches prior to their fusion with the operculum as well as afterwards. In Aristelliger praesignis this is apparently reversed; the epithelium of the third arch is very much thickened just prior to fusion with the operculum, but thereafter no filaments are to be observed, as if a somewhat premature fusion, as compared with conditions in other embryos, had inhibited the epithelial proliferation which had already started (H. E. C., Ser. 
1884; $4.9 \mathrm{~mm}$.$) . The same is true of Sphenodon punctatum$ (H. E. C., Ser. $1491 ; 7.9$ mm.).

In contrast with these lizards the snake Eutaenia presents a very interesting condition. So great is the lengthening process to which the body as a whole is subjected that the gill arches and clefts are obliterated by being drawn out instead of being crowded together. There is no opportunity for the formation of a peribranchial chamber nor even for a ventro-medial union of the two hyoid arches to form the plica opercularis, so characteristic of the Sauropsida as a whole. Consquently each hyoid arch is pulled back on the side of the trunk and there undergoes a further development by itself, persisting long after the other arches have lost their identity. Just before these disappaar (Eutaenia sirtalis, H. E. C., Ser. 1349; $7.6 \mathrm{~mm}$.; and E. radix, Ser. $13507.4 \mathrm{~mm}$.) the epithelium of the operculum (in the first case from the under side, in the second from the outer side) gives rise to a tuft of cells comparable in point of time and position with the filaments of the chick. Again, however, these are rather small and transitory appearances. To see structures in the reptile, closely comparable to those in the chick it is necessary to examine turtle embryos (Chrysemys, H. E. C., Ser. 1078; 10.0 $\mathrm{mm}$.; and Ser. $1083 ; 11.6 \mathrm{~mm}$.). The first of these (fig. 22) has been placed bes:de a chick embryo of exactly the same size (fig. 21 , H. E. C., Ser. 2038; $10.0 \mathrm{~mm}$.), which happily was so sectioned as to permit a very striking comparison of the two embryos, even to such details as the aortic arches, cephalic veins, etc. A glance at the operculum and its underlying filaments in the two specimens shows that at least in the stage at hand we are dealing with almost identical structures. Again, however, these filaments have but an ephemeral existence as compared with the development which the same structures undergo in the chick.

\section{DISCUSSION OF LITERATURE}

Of considerable interest in connection with this paper is the exhaustive work of Ekman on the branchial region of the Anura. He conducted a series of experiments to determine the various factors involved in the production of gill filaments in frogs and 
toads. He was able to show by transplantation methods that the ectoderm of the branchial region and immediately adjacent territory has a certain specificity for building gill filaments not possessed by the remaining ectoderm of the embryo; that a polarity of this ectoderm can be demonstrated; and that even when the entoderm and mesoderm underlying the future gill region in very young embryos are removed the ectoderm alone will produce abortive filaments devoid of blood vessels. It is the ectoderm of this same region in reptiles and birds which produces rudimentary filaments and they bear at least a superficial resemblance to some of the abortive structures thus produced experimentally in amphibia by Ekman (cf. figs, 26 and 27). In the case of the higher vertebrates the process never passes beyond the initial stages as evidenced by the early appearance of degeneration vesicles and the failure of blood vessels to participate in gill formation.

In the light of Ekman's experiments and the evidence presented in this paper it is doubtful whether the entodermal invagination which Grosser found in the first pharyngeal pouches of young human embryos has been rightly interpreted as an internal rudimentary gill. Grosser recorded his observations as follows:

A remarkable observation has been made by the author in all young embryos with the first pharyngeal pouches well developed; these are the embryos R. Meyer 335, Hal 2 Pfannenstiel III (loaned for this purpose), R. Meyer 330, and also a somewhat pathological, young embryo from the collection of R. Meyer. In the region of the first pouch there projects ventrally (figs. 315 and 316) or caudally (fig. 318) from the closing membrane into the pharyngeal lumen an irregularly knobbed process filled with mesoderm. That it is an accidental structure or due to post-mortem changes seems to be excluded by the regularity of its occurrence (Low has figured, but not described it). It disappears quite early (in the oldest embryo examined, figure 318) it is present only on the left side and is greatly reduced in size; in embryos of 4.25 5.0 and $5.8 \mathrm{~mm}$. and in those still older, it is wanting), and may perhaps be intcrpreted as a rudimentary internal gill. ${ }^{4}$ It would not be the first instance of a very ancient rudiment well developed in the human embryo. Similar structures have not yet been observed in other amniote embryôs. (Keibel \& Mall Human Embryology, 1912).

- Italicized by the author of the present paper. 
In his description of embryo "Robert Meyer No. 335," the same author ('11) figures a section of the "gill rudiment" which he describes as follows:

Das Relief der Gegend der ersten Tasche wird hauptsächlich von der erwähnten, in das Lumen des Vorderdarmes vorragenden Einstülpung beherrscht; sie mag vorläufig als Kiemenrudiment ${ }^{4}$ bezeichnet werden. Das Kiemenrudiment liegt jederseits ventral und zum Teil kranial von der Berührungsstelle der Epithelien, kaudal vom ersten Aortenbogen und ragt zapfenförmig dorsal und kaudalwärts in das Lumen der Darmbucht vor. In seinem Inneren findet sich ein mesodermaler Kern, Gefässe sind aber in diesem nicht mit vollen Sicherheit nachzuweisen.

There are at least three difficulties in the way of accepting Grosser's interpretation, the first of which involves the entodermal origin of the structure he presents as a gill filament. Kingsley states in his Comparative Morphology, that the gills of vertebrates "were long regarded as of entodermal origin but in recent years considerable doubt has been thrown on this; at least for fishes, and there is some evidence for their ectodermal origin." Ekman has shown that the ectoderm alone can produce abortive filaments in frogs and toads, while the evidence of the present paper establishes the fact that in the Sauropsida the filamentous structures which have been described as vestigial gills are wholly ectodermal. Another factor unfavorable to Grosser's interpretation is the position of this structure in the auditory pouch. If gills have persisted at all in so highly developed an animal as man, it is not likely that they would persist on arches which least commonly possess gills in water-breathing vertebrates. For with the exception of a few cyclostomes and fishes, gills are never found in the hyomandibular cleft. Again, the time of development is against Grosser's interpretation. The inpocketing which he describes first appears at a time when only the first two entodermal pouches have been formed (Embryo R. M. $335,1.73 \mathrm{~mm} ., 9$ to 10 somites) and when the second has not yet reached the ectoderm. It is last met with in embryos no older than R. M. 300 (2.5 m m., 23 somites) where only the first three pouches have reached the ectoderm. In fishes the functional gills are never formed before all the clefts have broken 
through, at a considerably older stage than that represented by the human embryos under discussion. Unless, therefore, something similar can be found in the branchial region of the lower vertebrates, it hardly seems as if the structure described by Grosser could be regarded as an internal rudimentary gill. With more likelihood it may be compared with thosc outpocketings in the preauditory region of the pharynx of the chick which Kastschenko as doubtfully considered "vermutliche rudimentäre Schlundtaschen."

Apparently filaments do not occur in mammals. The extensive series of mammalian embryos which are available in the Harvard Collection have been searched in vain for traces of filaments comparable with those already described for the Sauropsida. Reviewing the phylogeny of the branchial system of vertebrates in the light of these facts, it would seem that the gills of the lowest vertebrates have given place to functionless homologues in the Sauropsida and that with the further reduction which the branchial system has undergone in mammals all traces of even vestigial filaments have disappeared.

\section{CONCLUSIONS}

In the Sauropsida the development of the branchial region is characterized by the formation and relatively late persistence of a band of tissue across the ventral surface of the neck, which has been derived from the ventral union of the hyoid arches, and which may be known from its resemblance to the development of the gill cover of certain fishes and amphibians as the opercular fold or plica opereularis (Kiemendeckelwulst of German authors).

On the lateral margins of this operculum, after it has grown backward to enclose at least a potential peribranchial chamber, filamentous outgrowths may be observed on its under side, which in reptiles have a very transitory existence but which in the chick undergo a relatively extensive and prolonged development.

On account of the filamentous character of these outgrowths, their origin from the branchial arches (the epithelium of which Ekman has shown to possess a certain specificity for gill-formation in the Anura), and their constant relation to the operculum 
in both reptiles and birds, these structures are adjudged to be true gill filaments, evidently vestigial in character, but none the less comparable in kind to the functional organs of water-breathing anamniotes.

If this interpretation proves to be correct an unbroken series of gill-bearing vertebrates is thus presented from fishes up to mammals.

\section{LITERATURE CITED}

Ekman, GunNar 1913 Experimentelle Untersuchungen über die Entwicklung der Kiemenregion (Kiemenfäden und Kiemenspalten) einiger anuren Amphibian. Morph. Jahrb., Bd. 47, S. 419-575.

Evans, H. E. 1912 The development of the veins of the body wall. Keibel and Mall, Human Embryology, vol. 2, p. 686.

Grkil, A. 1906 Ueber die Homologie der Anammierkiemen. Anat. Hefte., Bd. 28 , S. $59-60$.

Grosser, Otto 1911 Zur Entwicklung des Vorderdarmes menschlicher Embryonen bis $5 \mathrm{~mm}$. grösster Länge. Sitzber. K. Akad. Wiss. Wien, vol. 120, p. 7 .

1912 The development of the pharynx and of the organs of respiration. Kiebel and Mall, Human Embryology, vol. 2, p. 454.

Kastschenko, N. 1887 Das Schlundspaltengebiet des Hühnchens, Arch. f. Anat. u. Entwickel., p. 258 .

Kingsley, J. S. 1912 Comparative anatomy of vertebrates. Blakistons 1912. p. 237.

Költriker, A. 1884 Grundriss der Entwickelungsgeschichte. p. 103.

MALL, F. P. 1898 The development of the ventral abdominal walls in man. Jour. Morph., vol. 14, p. 361.

Nassonow, N. 1895 Ueber das Operculum der Embryonen des Struthio camelus, L. Zool. Anz., Bd. 18. Jahrg. N. 492. p. 487.

Parker, T. Jefrries 1892 Observations on the anatomy and development of Apteryx. Phil. Trans. Roy. Soc., vol. 182.

RathKe, H. 1825 Isis, H. 6.

1832 Anatomisch-philosophische Untersuchungen über den Kiemenapparat und das Zungenbein der Wirbelthiere. Riga und Dortat.

1839 Entwickelungsgeschichte der Natter. Koenigsberg. p. 60-65.

1861 Entwickelungsgeschichte der Wirbelthiere. Leipzig. p. 71.

REMaK, R. 1851-55 Untersuchungen über die Entwickelung der Wirbelthiere. I. Ueber die Entwicklung des Hühnchens im Eie. Berlin. 1851. p. 44-49. 


\section{PLATE 1}

EXPLANATION OF FIGURES

Development of gill filaments in chick embryos of the fourth to the eighth day of incubation

4 Chick; 3 days, 4 hours; $6.8 \mathrm{~mm}$. $\times 9$ diam. (H. E. C., Ser. 2057) $I-I V$, first four ectodermal grooves (cf. with fig. 10).

5 Chick; 3 days, 22 hours; $8.1 \mathrm{~mm}$. $\times 9$ diam. (cf. with fig. 11). Note hillock on third areh.

6 Chick; 4 days, 23 hours; $13.4 \mathrm{~mm}$. $\times 9$ diam. I, auditory groove; $I I$, $I I I$, second and third ectodermal grooves limiting the wedge out of which the filaments are differentiating (cf. with figs. 18 and 19).

7 Chick; 6 days, 3 hours; $16.9 \mathrm{~mm}$. $\times 6$ diam. $I I$, site of the second ectodermal groove, occupied by a ridge bearing filaments; $S . P$., pectoral groove.

8 Chick; 6 days, 5 hours; $\times 6$ diam. (cf. with figs. 1 and 20 ).

9 Chick; 7 days, 1 hour; $19.7 \mathrm{~mm}$. $\times 6$ diam. 
EDWARD A. BOYDEN

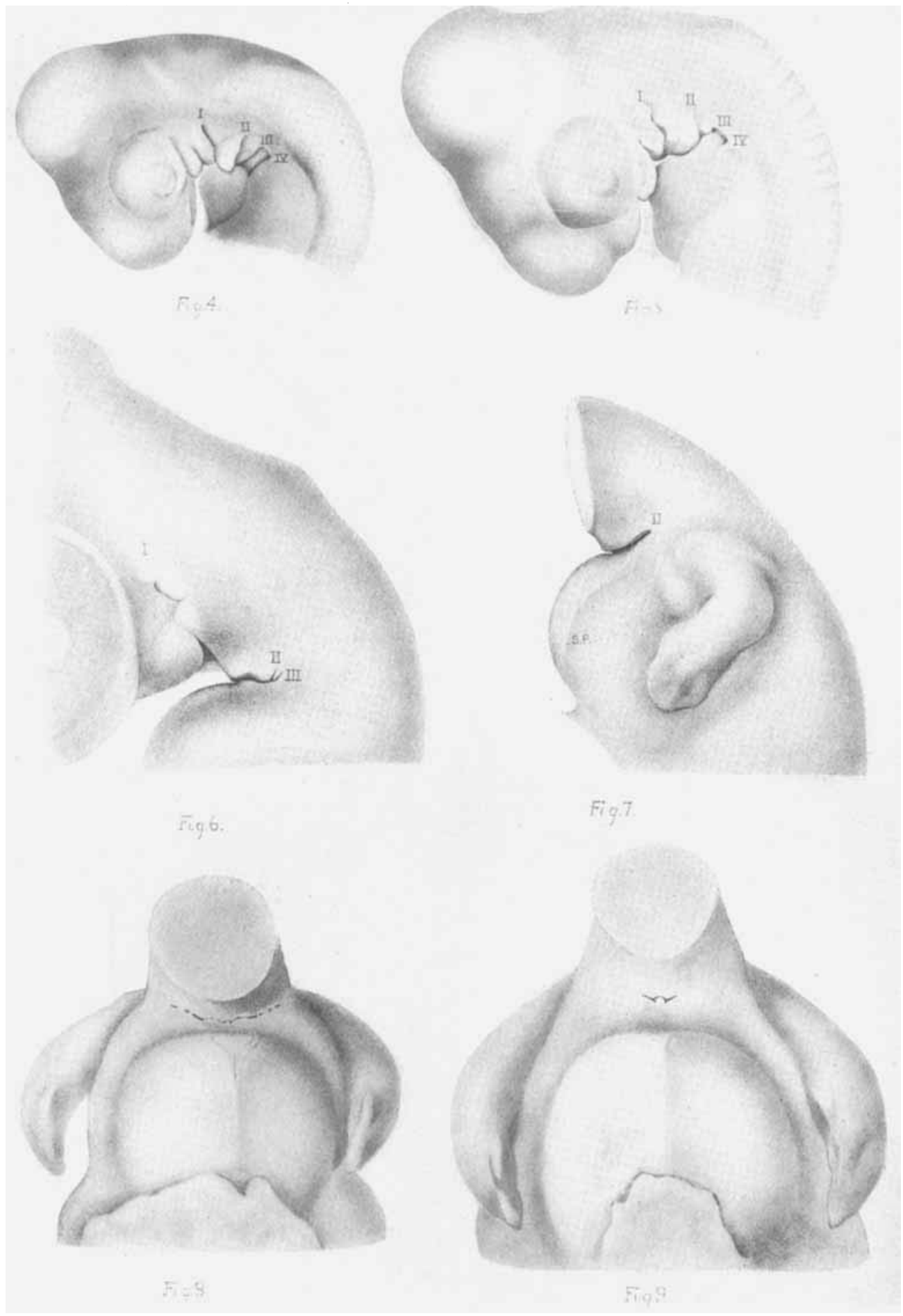

229

THE AMERICAN JOCRNAL OF ANATOMY, VOL. 23, NO. 1 


\section{PLATE 2}

\section{EXPLANATION OF FIGURES}

Sections illustrating early development of filaments

10 Section through the branchial clefts of an embryo of 3 days and 4 hours (H. E. C., Scr. $2057 ; 6.8 \mathrm{~mm}$; section $266 ; \times 27$ diam.), illustrating the stage when vesicles first appear in the branchial epithelium (cf. with fig. 4). $I-I V$ ectodermal grooves; op., operculum.

11 Section of an embryo of 4 days and 4 hours (H. E. C., Ser. $2058 ; 11.0 \mathrm{~mm}$.; section $482 ; \times 27$ diam.), illustrating the stage when vesicles become concentrated in the ectoderm of the third and fourth arches (cf. with fig. 5). Note the thickened epithelium covering the mound on the third arch. 3, 4, 6, aortie arches.

12 to 17 Consecutive serial sections of an embryo of 4 days and 3 hours ( $H$. E. C., Ser. $1943 ; 12.0 \mathrm{~mm}$.; sections 215 to 220 respectively, $\times 27$ diam.). The first three, on the left, show the mound which forms on the third areh and its mesodermal core; the last thrce, on the right, show the thickened epithelium at the lower end of the mound, out of which the first filaments are differentiating.

$12 I, I I, I I I$, ectodermal grooves; $I I, I I I, I V$, pharyngeal diverticula.

$15 E-I I I, E-I V$, evaginations of the ectodermal epithelium on the third and fourth arches, respectively. 
EDWARD A. BOYOEN
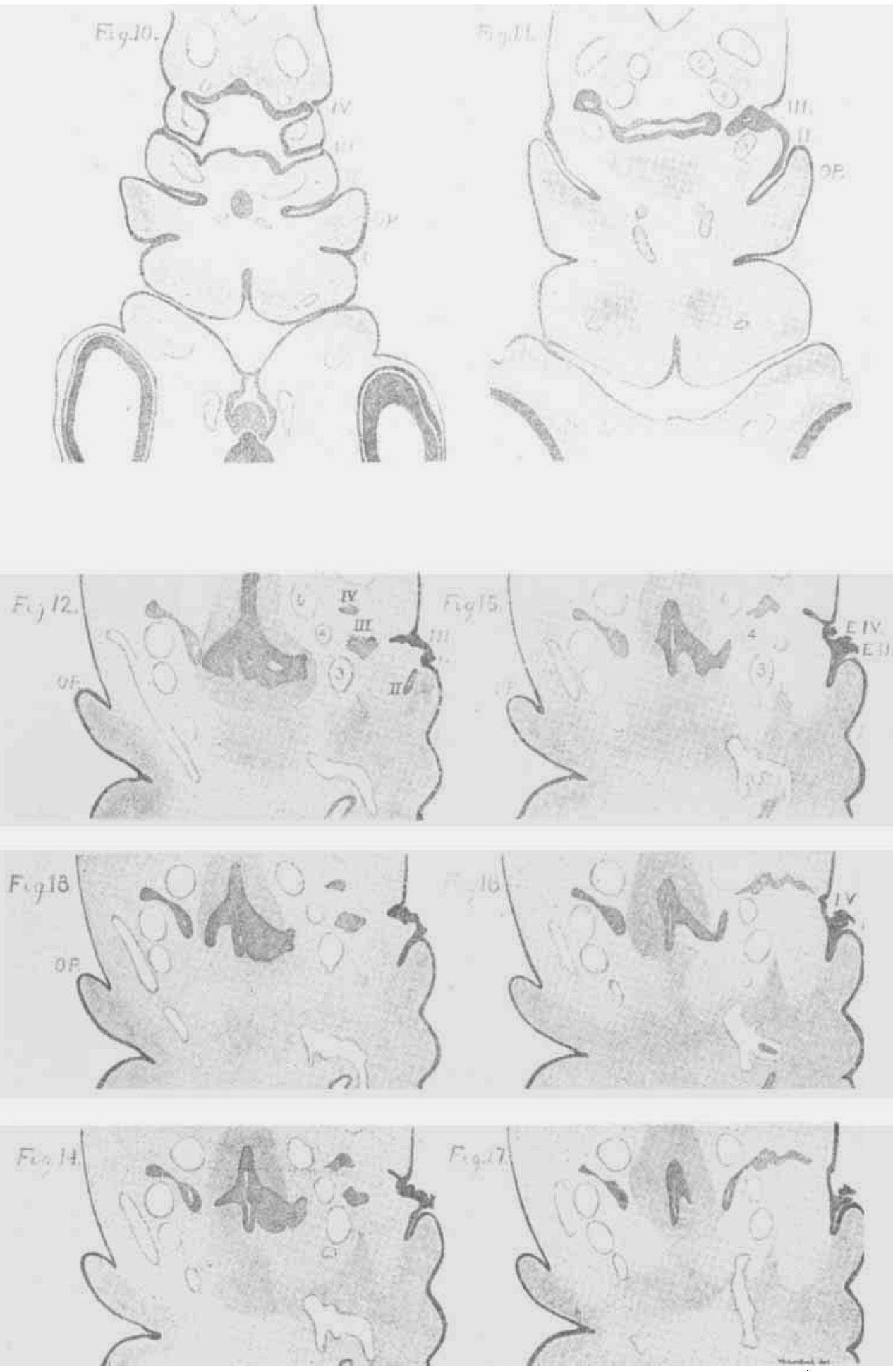
PLATE 3

EXPIANATION OF FIGURES

Sections illustrating later development of filaments

18 and 19 Sections through the hyoid region of an embryo of 5 days; $3.0 \mathrm{~mm}$. (H. E. C., Ser. 1951 ; sections 245 and 247 respectively) $\times 67$ diam. 3, 4, 6, aortic arehes; $I I$, second ectodermal groove; III, diverticulum of third pouth; $o p$., operculum; $f_{1}$, filaments at the upper end of the 'wedge;' $f_{2}$, filaments at, the point of the 'wedge' (ef. with fig. 6).

20 Frontal section through the opercular fold and pectoral wall of an embryo of 6 days and 2 hours; $16.0 \mathrm{~mm}$. (H. F. C., Ser. 1950; section 901) $\times 67$ dium. (of. with fig. 8). op., operculum; $f$, branched filaments; s.p., pectoral grooves; $c . m$., mesothelial ridge; b.c., bulbus cordis; $p$., pericardial cavity; c.p., thickened opithelium which gives rise to the pectoral ridges.

21 Filaments of a $10.0 \mathrm{~mm}$. chick (H. E. C., Ser. 2038; 5 days; section 572) $\times 67$ diam. (ef. with fig. 22). 3, 4, 6 aorlis arches; $I I, I V$, diverticulum of third and fourth pouch; $e$., esophagus; $t r$., trachea; $p$., pericardial eavity.

22 Filaments of a $10.0 \mathrm{~mm}$. turtle cmbryo (H. E. C., Ser. 1078 Chrysenys marginato, section 286$) \times 67$ diam. 



\section{PLATE 4}

\section{EXPIANATION OF FIGURES}

23 Low power sketch of opcrculum and filament from a chick embryo of 4 days and 23 hours (H. E. C., Ser. 2059; 14.0 mm.; section 1004) $\times 50$ diam.

24 High power sketch from same section as figure 23 showing longitudinal section of an opercular filament. Camera lucida drawing $\times 750$ diam. ect., ectoderm covering the under surface of the opereulum; mes., underlying mesenchyma.

25 Fpithelial eyst in process of formation. Camera lucida drawing of section 207. $\times 900$ diam. (H. F. C., Ser. 1954; 4 days, 3 hours; 9.0 mm.). est., ectoderm covering the fourth branchial arch; mes., underlying mesenchyma. The vesicle figured measures $19 \mu$ in diameter.

26 After Ekman's figure 29: "Horizontalschnitt durch dic Kiemongegond einer Bombinator-Larvo 3 Tage nach der Entfernung der ontodermalen Mundhöhlenwand im I. Stadium. Bg. Blutgcfässe; KI-III 1-3. Kiemenreihe; Op., Operculum." $\times 200 \mathrm{diam}$.

27 Section through the hyoid region of a $12.0 \mathrm{~mm}$. chick (5 days, 1 hour, $\times 100$ diam.), for comparison between the normally oecurring vestigial filaments and opercular fold of the chick and the abortive filaments and peribranchial chamber experimentally produced in tond embryos by Fkman (cf. with fig. 26). 

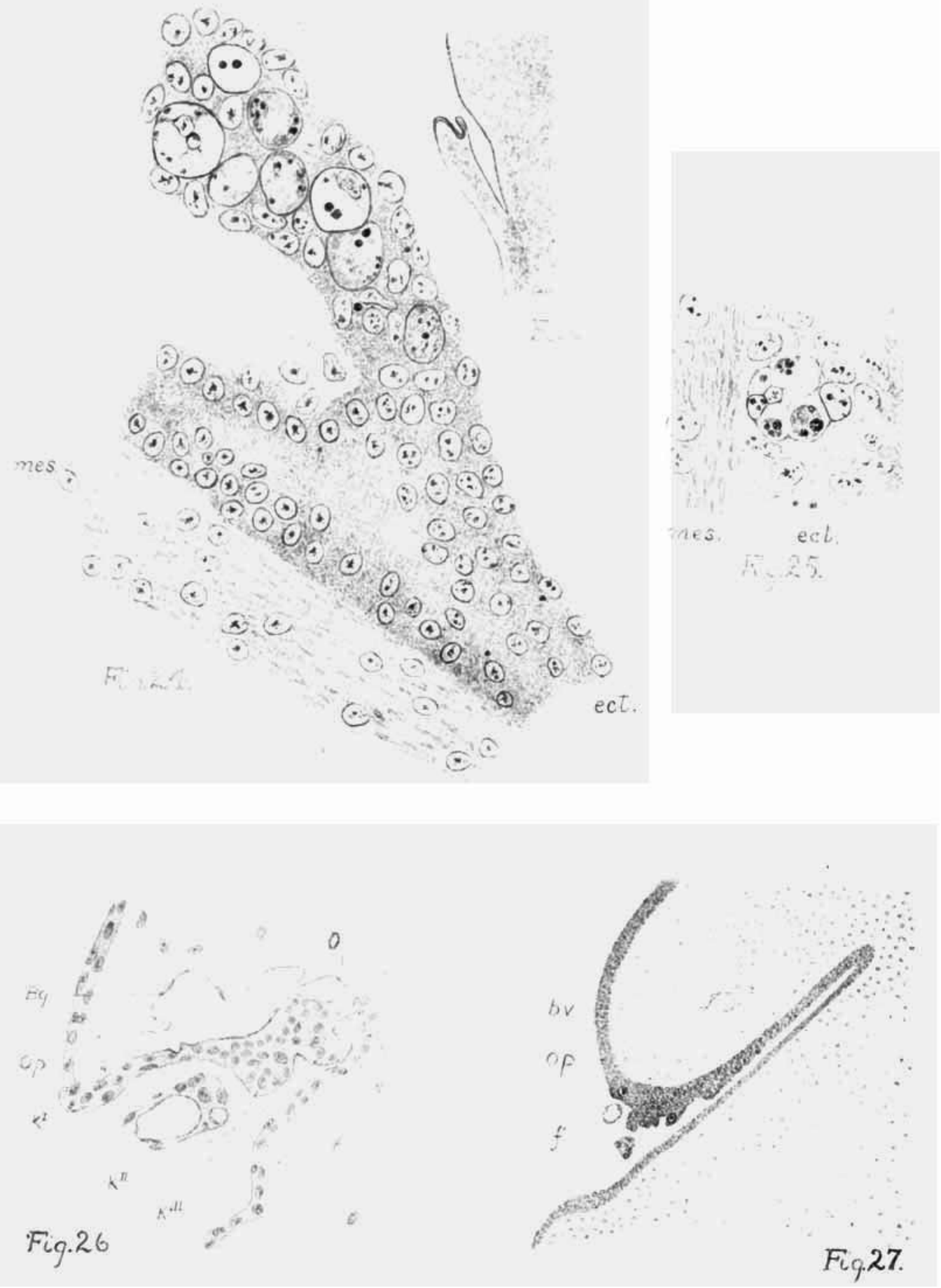